\title{
CAMPO JURÍDICO E POLÍTICAS DO BIODIESEL: AGRICULTURA FAMILIAR E EFETIVIDADE DA NORMA
}

\section{LEGAL FIELD AND POLICIES OF BIODIESEL: FAMILIAR AGRICULTURE AND LAW EFFECTIVENESS}

\begin{abstract}
BRUNO CÉSAR GURSKI
Eng. Agrônomo, Advogado, Doutorando em Solos e Meio Ambiente pela Universidade Federal do Paraná (UFPR), Curitiba, Paraná, Brasil. brunogurski@ufpr.br

JosÉ EDMILSON SOUZA LIMA

Doutor e Pós-Doutor em Meio Ambiente e Desenvolvimento pela Universidade Federal do Paraná (UFPR), pesquisador associado do Programa de Pós-Graduação em Meio Ambiente e Desenvolvimento (UFPR), pesquisador e docente do Mestrado em Direito do Centro Universitário Curitiba (UNICURITIBA), Curitiba, Paraná, Brasil.
\end{abstract}

zecaed@hotmail.com

\begin{abstract}
RESUMO
Objetiva-se refletir sobre o poder da norma jurídica como instrumento de concretização dos objetivos institucionais associados às políticas do biodiesel no Brasil. Metodologicamente, o estudo ancora-se em pesquisa bibliográfica e documental. Concluiu-se que há aspectos que extrapolam o campo jurídico que influenciam diretamente na teleologia normativa, como o conflito de interesses no processo legislativo. A norma jurídica sobre o biodiesel apresenta antinomias e lacunas, que são a causa do insucesso do Programa Nacional de Produção e Uso de Biodiesel, voltado a fomentar a melhoria social da agricultura familiar brasileira. Por isso, a transversalidade da norma, proveniente principalmente da Política Energética Nacional, não surtiu o efeito esperado nas normas instrumentais das políticas públicas propostas para o setor. Há necessidade do campo jurídico dialogar com outros campos de conhecimento, com vistas a incorporar fatos alheios ao Direito em suas aplicações da norma no mundo concreto.
\end{abstract}

Palavras-chave: Biocombustível; Direito; Energias Renováveis; Produção; Transversalidade.

\begin{abstract}
This work aims to reflect on the power of the law as an instrument of implementation of institutional objectives associated with the biodiesel policies in Brazil. Methodologically, the study used bibliographic and documentary research. The main conclusions are that there are aspects that go beyond the legal field which directly influence the normative teleology, such as the conflict of interests in the legislative process. The law about biodiesel presents antinomies and gaps, which are the cause of the failure of the National Program for Production and Use of Biodiesel, aimed to promote the social improvement of the Brazilian familiar agriculture. Therefore, the transversality of the law, mainly from the National Energy Policy, did not have the expected effect on instrumental rules of public policy proposals for the sector. There is a need in the legal field to dialogue with other fields of knowledge, in order to incorporate other factors than the law in its application in the real world.
\end{abstract}

Keywords: Biofuel; Law; Renewable Energy; Production; Transversality. 


\section{SUMÁRIO}

INTRODUÇAO; 1 CRISE SOCIOAMBIENTAL E ENERGIAS; 2 TRANSVERSALIDADE DA NORMA; 3 NORMA JURÍDICA E POLÍTICA ENERGÉTICA DO BIODIESEL; 4 NORMATIVAS DO BIODIESEL E AGRICULTURA FAMILIAR BRASILEIRA; 5 ASPECTOS NÃO JURÍDICOS DA NORMA SOBRE BIODIESEL; CONCLUSÃO; REFERÊNCIAS.

\section{INTRODUÇÃO}

Em certa medida, o debate em torno da crise socioambiental contemporânea tende a caracterizá-la como reflexo das tentativas frustradas de se chegar ao desenvolvimento sustentável, demandando dos atores sociais soluções teóricas e práticas com pretensões sustentáveis. Nessa perspectiva, o Direito da Energia herda todos os princípios e mecanismos próprios do Direito Ambiental, com vistas a contribuir não apenas denunciando as dificuldades e obstáculos derivados da questão energética, mas sobretudo intervindo positivamente por meio da aplicação das normativas.

O território brasileiro é bastante heterogêneo em relação aos recursos naturais existentes para a geração de energia das mais variadas fontes. No entanto, outros fatores como a economia, política e bem-estar social influenciam diretamente na matriz energética brasileira. Entender esse relacionamento histórico no contexto atual é fundamental para sua melhoria. Para isso, é imperativo indagar qual a influência recíproca entre norma jurídica e energia e seus reflexos no campo específico do biodiesel no Brasil, para a solução das questões suscitadas pela crise socioambiental?

Com vistas a buscar resposta à pergunta, este artigo teve como objetivo refletir sobre o poder da norma jurídica projetar-se como instrumento de concretização dos objetivos institucionais associados às políticas de biodiesel no Brasil. Em termos metodológicos, a pesquisa fez uso de técnicas bibliográficas e documentais.

0 artigo, além da introdução e das considerações finais, está estruturado em cinco seções contendo um estado da arte acerca da questão ambiental e no interior desta, a questão energética com acento no biodiesel. Além deste estado arte, é apresentado o arcabouço jurídico que regula a questão energética associada ao biodiesel. Por fim, traz algumas ponderações sobre 
os limites e as potencialidades da normativa em fazer valer os objetivos socioambientais e econômicos da política energética brasileira.

\section{CRISE SOCIOAMBIENTAL E ENERGIAS}

Para alguns autores ${ }^{1}$, a Pós-Modernidade vem se configurando como crise da própria Modernidade em que ocorre de forma simultânea a afirmação e a destituição da racionalidade ${ }^{2}$ que sustenta a sociedade capitalista. Os fatores da atual crise socioambiental vão além da eventual falta de compreensão dos riscos ambientais existentes ou da pouca vontade política para tratar desses temas. Eles desafiam todos os setores da sociedade a encontrar soluções abrangentes e complexas que em vez de separar, aproximem e incorporem as capacidades das ciências, da técnica e das instituições políticas e culturais existentes.

Atualmente, parece haver um consenso de que alguns aspectos importantes do atual modelo civilizatório carecem de mudanças, com vistas proporcionar uma aproximação entre critérios ecológicos e a dinâmica social, pois a espécie humana começa a se dar conta de que corre riscos de sobrevivência no longo prazo $^{3}$. Isto porque, caracterizada pela ideia de limitação e tempo de renovação dos recursos naturais preconizada por Meadows e outros, a crise socioambiental impõe questionamentos da atual racionalidade e a construção de uma nova, centrada na ideia de interdisciplinaridade, como perspectiva transformadora dos paradigmas atuais do conhecimento, hibridação das ciências, tecnologias e dos saberes ${ }^{4}$.

No contexto de crise socioambiental, no campo energético, as principais fontes renováveis e não-renováveis estão localizadas nos países emergentes, constituindo-se para estes, ao mesmo tempo, riqueza à qual não têm acesso e miséria em razão das formas por meio das quais as grandes empresas transnacionais energéticas, com apoio dos Estados onde estão sediadas, exploram tais recursos. Essa realidade constitui-se em um dos principais empecilhos para o Direito, pois tende a inviabilizar a aplicação de diretivas que proporcionem

\footnotetext{
1 FLORIANI, D. Crítica da razão ambiental: pensamento e ação para a sustentabilidade. São Paulo: Annablume, 2013.

${ }^{2} \mathrm{O}$ conceito de racionalidade está sendo usado como um sistema de crenças e valores que serve de referência para orientar ações e decisões individuais e/ou coletivas.

${ }^{3}$ LEIS, H. R. A Modernidade (in)sustentável. Petrópolis: Vozes, 1999.

${ }^{4}$ MEADOWS, D.; MEADOWS, D.; RANDERS, J; BEHRENS, W. W. Limites do crescimento. 2.ed. São Paulo: Editora Perspectiva, 1978.
} 
desenvolvimento com pretensões sustentáveis em termos econômicos, sociais e ambientais para as sociedades locais.

As principais reservas de petróleo e gás estão nos países do Oriente Médio $(60 \%)$ e o restante concentra-se no litoral ocidental da África, na América Latina, no sudeste da Ásia e Rússia ${ }^{5}$. Este panorama de dados acerca das fontes não renováveis de energia fortalece e justifica a necessidade do Brasil avançar no debate público em torno das energias renováveis. Os biocombustíveis projetam-se como um dos temas relevantes para o Brasil, à medida que reivindicam posição de destaque na pauta de discussão das energias renováveis e limpas ${ }^{6}$.

\section{TRANSVERSALIDADE DA NORMA}

Paralelamente ao processo de industrialização dos países no século $\mathrm{XX}$, houve expansão normativa e mudança no conteúdo das normas que passaram a ser orientadas pela eficiência e maximização da riqueza. Nesta linha de raciocínio, Alves estabelece que o conteúdo material dos comportamentos exigidos sob a nova ótica moderna exige uma reorganização da ordem jurídica focada na nova realidade social e econômica, advinda da reflexão sobre quais as bases jurídicas que devem nortear a nova racionalidade humana. O “novo Direito" exige controles cada vez mais aprimorados e eficazes, necessitando da criação, aperfeiçoamento e ampliação acelerados da norma jurídica ${ }^{7}$.

Antunes e Alves também acreditam que as relações entre homem e natureza vêm se modificando de forma acelerada e profunda e o Direito surge como instrumento de mediação nessa realidade, é marco regulatório e normativo das atividades humanas em relação à energia ${ }^{8}$ 9. Se o Direito se defronta com questões que não são de sua competência, precisa recorrer a outros instrumentos e saberes para aperfeiçoar a eficácia técnica, pois a norma perde eficácia quando the faltam elementos essenciais para sua implementação. As outras fontes do Direito,

\footnotetext{
${ }^{5}$ PeReIRA, A. C. A.; PEREIRA, J. E. A. O direito à energia no contexto dos humanos. Sequência, n. 53, p. 29-42, dez., 2006.

${ }^{6}$ DANTAS, M. R.; PINHEIRO, R. J. Marco jurídico do biodiesel e o modelo regulatório brasileiro. Direito Energia. Ano 5, v. 8, 2013.

${ }^{7}$ ALVES, A. C. Fundamentos do Direito e meio ambiente. In: PHILIPPHI JR., A.; ALVES, A. C. (Editores). Curso interdisciplinar de direito ambiental. São Paulo: Manole, 2005.

${ }^{8}$ ANTUNES, P. B. Direito ambiental. 1. ed. São Paulo: Atlas, 2013. 1433 p.

${ }^{9}$ ALVES, A. C. Fundamentos do Direito e meio ambiente. In: PHILIPPHI JR., A.; ALVES, A. C. (Editores). Curso interdisciplinar de direito ambiental. São Paulo: Manole, 2005.
} 
que não as jurídicas, servem de subsídio, transferem consistência e objetividade e, por sua vez, o Direito lhes transmite a legitimidade na aplicação em face da coisa pública e do bem comum ${ }^{10}$.

Neste contexto, para Antunes, o Direito Ambiental consegue fazer incursões em diversas áreas do conhecimento humano, com propósitos de aperfeiçoar sua capacidade de aplicação da norma jurídica. Este diálogo com saberes não jurídicos e com situações extralegais, distingue o Direito Ambiental dos outros ramos do Direito. Para este autor, a relação do Direito Ambiental com os demais ramos do Direito, dentre eles o direito da energia, é transversal, à medida que insere nas demais normas jurídicas a noção de cuidado e proteção do meio ambiente. Além do que, inclui a noção de participação e manifestação do cidadão na resolução dos problemas socioambientais ${ }^{11}$.

A transversalidade das normas ambientais quer dizer que penetram horizontalmente nos vários ramos de disciplinas tradicionais ${ }^{12}$. Consiste em uma interação que faz com que todos assumam a teleologia normativa como possibilidade objetiva de transformação não apenas da norma jurídica em sentido abstrato, mas da realidade socioambiental concreta ${ }^{13}$.

\section{NORMA JURÍDICA E POLÍTICA ENERGÉTICA DO BIODIESEL}

As mudanças normativas em relação aos biocombustíveis têm origem, segundo Sanches, no chamado segundo modelo energético brasileiro. A partir de 2004, época marcadamente influenciada pela globalização do petróleo, guerra dos Estados Unidos contra o Iraque, instabilidade política na Venezuela e no Brasil, desafios estruturais com início do governo Lula. Neste cenário, a Petrobras não buscava mais a auto-suficiência petrolífera, mas alastramento da presença global no setor. O governo da época investiu no desenvolvimento de programas governamentais que pudessem produzir ou aumentar a demanda na área energética, dentre eles a inserção do biodiesel na matriz energética brasileira e reestruturação da Agência Nacional do Petróleo (ANP) para regular esse mercado ${ }^{14}$.

\footnotetext{
${ }^{10}$ MILARÉ, É. Direito do ambiente. 8. ed. São Paulo: Revista dos Tribunais, 2013.

${ }^{11}$ ANTUNES, P. B. Direito ambiental. 1. ed. São Paulo: Atlas, 2013. 1433 p.

12 LEITE, J. R. M. \& AYALA, P. A. Direito ambiental na sociedade de risco. Rio de Janeiro: Forense Universitária, 2002.

${ }^{13}$ ANTUNES, P. B. Direito ambiental. 1. ed. São Paulo: Atlas, 2013. 1433 p.

14 SANCHES, L. A. U. Curso de direito da energia: da história, tomo I. São Paulo: Instituto Geodireito, 2011.
} 
Neste sentido, a experiência agrícola brasileira acumulada, associada à necessidade de desenvolvimento dos pequenos produtores rurais, carentes de políticas públicas sociais, bem como a pressão ambiental e, por fim, a oportunidade de tornar o Brasil líder na política de biocombustíveis, ocasionou um aumento expressivo na produção do biodiesel a partir de plantas oleaginosas como a mamona, pinhão manso, dendê, girassol, dentre outras ${ }^{15}$.

A maioria das modificações normativas para a inserção do biodiesel na matriz energética brasileira se deu por meio da Lei $n^{\circ}$ 9.478, de 6 de agosto de 1997, que dispõe sobre a política energética nacional. A primeira norma incentivadora dentro do novo modelo energético brasileiro voltado à inserção do biodiesel na matriz brasileira foi a Lei $n^{\circ} 11.097$, de 13 de janeiro de 2005 que estabeleceu como principais medidas: criação do Programa Nacional de Produção e Uso do Biodiesel (PNPB) para monitorar o mercado; atribuição de competência à ANP para regular a cadeia produtiva e o uso do biodiesel; estabelecimento de percentuais de mistura ao diesel convencional; entre outras ${ }^{16}$.

Art. $1^{\circ}$ As políticas nacionais para o aproveitamento racional das fontes de energia visarão aos seguintes objetivos:

[...]

XII - incrementar, em bases econômicas, sociais e ambientais, a participação dos biocombustíveis na matriz energética nacional; (Redação dada pela Lei $\mathrm{n}^{\circ}$ 11.097, de 2005)

Art. $2^{\circ}$ Fica criado o Conselho Nacional de Política Energética - CNPE, vinculado à Presidência da República e presidido pelo Ministro de Estado de Minas e Energia, com a atribuição de propor ao Presidente da República políticas nacionais e medidas específicas destinadas a:

[...]

IV - estabelecer diretrizes para programas específicos, como os de uso do gás natural, do carvão, da energia termonuclear, dos biocombustíveis, da energia solar, da energia eólica e da energia proveniente de outras fontes alternativas; (Redação dada pela Lei $n^{\circ} 11.097$, de 2005)

Art. $6^{\circ}$ Para os fins desta Lei e de sua regulamentação, ficam estabelecidas as seguintes definições:

$[\ldots]$

XXV - Biodiesel: biocombustível derivado de biomassa renovável para uso em motores a combustão interna com ignição por compressão ou, conforme regulamento, para geração de outro tipo de energia, que possa substituir parcial ou totalmente combustíveis de origem fóssil. (Incluído pela Lei $\mathrm{n}^{\circ} 11.097$, de $2005)^{17}$.

\footnotetext{
${ }^{15}$ Ibidem.

${ }^{16}$ HALL, J.; MATOS, S.; SEVERINO, L. Brazilian biofuels and social exclusion: established and concentrated ethanol. Journal of Cleaner Production, 17:577-585, 2009. E, SANCHES, L. A. U. Curso de direito da energia: da história, tomo I. São Paulo: Instituto Geodireito, 2011, p.397.

${ }^{17}$ BRASIL. Lei $n^{\circ}$ 9.478, de 6 de agosto de 1997. Dispõe sobre a política energética nacional, as atividades relativas ao monopólio do petróleo, institui o Conselho Nacional de Política Energética e a Agência
} 
Logo em seguida, com o intuito de aumentar a produção de biodiesel no Brasil, principalmente na agricultura familiar, como dito anteriormente, houve mudança na redação original da Lei $n^{\circ} 11.097 / 05$, recém-vigente:

Art. 2o Fica introduzido o biodiesel na matriz energética brasileira, sendo fixado em 5\% (cinco por cento), em volume, o percentual mínimo obrigatório de adição de biodiesel ao óleo diesel comercializado ao consumidor final, em qualquer parte do território nacional.

§ 400 biodiesel necessário ao atendimento dos percentuais mencionados no caput deste artigo terá que ser processado, preferencialmente, a partir de matérias-primas produzidas por agricultor familiar, inclusive as resultantes de atividade extrativista. (Incluído pela Lei $n^{\circ} 11.116$, de 2005) ${ }^{18}$.

Naquele contexto, houve relatos de que o apoio político ao Programa Nacional de Produção e Uso do Biodiesel (PNPB) foi particularmente forte durante os primeiros anos, entre 2004 e $2005^{19}$, com previsão de destino de R\$ 100.000.000,00 do Programa Nacional da Agricultura Familiar (PRONAF), exclusivamente para a produção de biodiesel, com taxas de juros especiais, para alçar a agricultura familiar a uma posição de competitividade no mercado energético. Nesta mesma perspectiva havia previsão de uma linha de crédito disponibilizada pelo Banco Nacional do Desenvolvimento Social (BNDES) para o financiamento e comercialização do biodiesel ${ }^{20}$. Também foram lançados vários editais de leilão para compra de biodiesel pela Petrobrás em 2006 e 2007, principalmente na região Nordeste, baseados nas culturas da mamona, pinhão manso, palma e algodão, sendo que nesta região a Petrobrás decidiu construir várias usinas de biodiesel ${ }^{21}$.

A Petrobras Biocombustíveis, subsidiária integral da Petrobras foi criada em 2008 e atualmente, possui três usinas próprias de biodiesel, localizadas nos municípios de Candeias-BA,

Nacional do Petróleo e dá outras providências. Diário Oficial da República Federativa do Brasil. Brasília, DF, 7 ago. 1997. Disponível em: <http://www.planalto.gov.br/ccivil_03/LEIS/L9478.htm>. Acesso em 09 jun. 2015.

18 BRASIL. Lei $n^{\circ} 11.097$, de 13 de janeiro de 2005. Dispõe sobre a introdução do biodiesel na matriz energética brasileira; altera as Leis nos 9.478, de 6 de agosto de 1997, 9.847, de 26 de outubro de 1999 e 10.636, de 30 de dezembro de 2002; e dá outras providências. Diário Oficial da República Federativa do Brasil. Brasília, DF, 14 jan. 2005. Disponível em: <http://www.planalto.gov.br/ccivil_03/_ato20042006/2005/Lei/L11097.htm>. Acesso em: 09 jun. 2015.

${ }^{19}$ HALL, J.; MATOS, S.; SEVERINO, L. Brazilian biofuels and social exclusion: established and concentrated ethanol. Journal of Cleaner Production, 17:577-585, 2009.

${ }^{20}$ SANCHES, L. A. U. Curso de direito da energia: da história, tomo I. São Paulo: Instituto Geodireito, 2011.

${ }^{21}$ LEITE, A. D. A energia no Brasil. 2 ed. Rio de Janeiro: Elsevier, 2007. 
Quixadá-CE e Montes Claros-MG, e duas usinas nas cidades de Marialva-PR e Passo Fundo-RS, em parceria com a BSbios. A usina de Candeias foi inaugurada em 29 de julho de 2008, sendo a maior usina, com capacidade de produção de 217,2 milhões de litros de biodiesel por ano. A usina de Quixadá foi inaugurada em 20 de agosto de 2008 e a usina de Montes Claros foi inaugurada em 6 de abril de 2009, totalizando aproximadamente nove mil agricultores familiares, com área total de cerca de 19 mil hectares em seis estados do semiárido brasileiro e capacidade produtiva de 152,9 milhões de litros de biodiesel por ano ${ }^{22}$.

As usinas em parceria com a BSbios estão localizadas em Marialva, em que a Petrobrás detém metade do capital social da empresa, inaugurada em $1^{\circ}$ de dezembro de 2009 , e possui aproximadamente 10.000 agricultores familiares conveniados, produtores de soja no Estado do Paraná, e capacidade produtiva de 208,8 milhões de litros de biodiesel por ano. A outra está localizada em Passo Fundo, com participação paritária, inaugurada em $1^{\circ}$ de julho de 2011, conta com cerca de 24 mil agricultores familiares, produtores de soja e canola nos estados do Rio Grande do Sul e Santa Catarina, detém capacidade de produção de 216 milhões de litros de biodiesel por $\mathrm{ano}^{23}$.

A composição das fontes da matriz energética brasileira não variou muito ao longo dos anos (Tabela 1). Há um aparente equilíbrio equânime entre fontes não renováveis e fontes renováveis. Em um primeiro momento, pode-se aferir que todas essas mudanças normativas, econômicas e políticas surtiram o efeito desejado, porque as fontes renováveis classificadas como "outras renováveis" (Tabela 1) tiveram tendência crescente ao longo dos anos pesquisados. O biodiesel está inserido nesta classificação, no entanto, é necessário tomar cuidado com a análise dos dados, pois tal matriz é predominantemente agrícola, dependente do clima, sobretudo da crise hídrica mencionada, razão pela qual se faz necessário analisar dados específicos sobre a produção e composição das fontes de biodiesel para aferir quaisquer conclusões. Cumpre frisar que, a despeito dos avanços dos marcos legais e das iniciativas do governo, nos últimos anos pesquisados (2013 e 2014) a tendência foi a redução das fontes renováveis e o aumento das não renováveis.

\footnotetext{
22 PETROBRAS. Relatório de administração e balanço contábil de 2014. Rio de Janeiro: Petrobras Biocombustível S.A. 2015.

${ }^{23}$ PETROBRAS. Relatório de administração e balanço contábil de 2014. Rio de Janeiro: Petrobras Biocombustível S.A. 2015.
} 
Tabela 1. Composição percentual da matriz energética brasileira ${ }^{24}$.

\begin{tabular}{|c|c|c|c|c|c|c|c|c|c|c|}
\hline Fontes & 2005 & 2006 & 2007 & 2008 & 2009 & 2010 & 2011 & 2012 & 2013 & 2014 \\
\hline Não Renovável & 53,3 & 53,2 & 51,9 & 52,1 & 53,8 & 53,0 & 54,8 & 54,7 & 54,2 & 56,5 \\
\hline Petróleo & 42,0 & 42,1 & 40,6 & 39,7 & 42,0 & 42,1 & 42,5 & 41,7 & 40,6 & 42,8 \\
\hline Gás Natural & 8,8 & 8,3 & 8,1 & 9,0 & 8,7 & 9,0 & 9,3 & 10,0 & 10,8 & 11,6 \\
\hline Carvão Vapor & 1,2 & 1,0 & 1,0 & 1,1 & 0,8 & 0,8 & 0,8 & 1,0 & 1,3 & 1,1 \\
\hline Carvão Metalúrgico & 0,1 & 0,0 & 0,0 & 0,0 & 0,1 & 0,0 & 0,0 & 0,0 & 0,0 & 0,0 \\
\hline Urânio & 0,7 & 1,1 & 1,6 & 1,7 & 1,7 & 0,7 & 1,6 & 1,5 & 0,9 & 0,2 \\
\hline Outras Não Renováveis & 1,0 & 1,0 & 1,0 & 0,0 & 1,0 & 0,0 & 1,0 & 1,0 & 1,0 & 1,0 \\
\hline Renovável & 46,7 & 46,8 & 48,1 & 47,9 & 46,2 & 47,0 & 45,2 & 45,3 & 45,8 & 43,5 \\
\hline Hidráulica & 14,5 & 14,2 & 14,4 & 13,4 & 14,0 & 13,7 & 14,4 & 13,9 & 13,0 & 11,8 \\
\hline Lenha & 14,2 & 13,5 & 12,8 & 12,4 & 10,2 & 10,3 & 10,1 & 10,0 & 9,5 & 9,1 \\
\hline Biomassa cana-de-açúcar & 15,5 & 16,6 & 18,1 & 19,0 & 18,6 & 19,3 & 16,9 & 17,6 & 19,1 & 18,1 \\
\hline Outras Renováveis & 2,6 & 2,6 & 2,9 & 3,1 & 3,4 & 3,7 & 3,8 & 3,8 & 4,1 & 4,6 \\
\hline
\end{tabular}

FONTE: (EPE, 2015).

Apesar de todos os incentivos mencionados, percebeu-se por volta de 2010 e 2011 que os objetivos não tinham sido atingidos, houve injeção maciça de investimentos, mas a produção variava muito ao longo dos anos, por vários motivos descritos mais adiante. Então, o Estado julgou que havia necessidade de mais mudanças normativas para incentivo dos biocombustíveis na matriz energética brasileira. Com isso, as principais mudanças normativas ocorreram em 2011, com a constatação da falta de efetividade das medidas propostas em 2005.

Art. $1^{\circ}$ As políticas nacionais para o aproveitamento racional das fontes de energia visarão aos seguintes objetivos:

$[\ldots]$

XIII - garantir o fornecimento de biocombustíveis em todo o território nacional; (Incluído pela Lei $\mathrm{n}^{\circ} 12.490$, de 2011)

XIV - incentivar a geração de energia elétrica a partir da biomassa e de subprodutos da produção de biocombustíveis, em razão do seu caráter limpo, renovável e complementar à fonte hidráulica; (Incluído pela Lei $\mathrm{n}^{\circ} 12.490$, de 2011)

$\mathrm{XV}$ - promover a competitividade do País no mercado internacional de biocombustíveis; (Incluído pela Lei $\mathrm{n}^{\circ} 12.490$, de 2011)

XVI - atrair investimentos em infraestrutura para transporte e estocagem de biocombustíveis; (Incluído pela Lei $n^{\circ} 12.490$, de 2011)

XVII - fomentar a pesquisa e o desenvolvimento relacionados à energia renovável; (Incluído pela Lei $\mathrm{n}^{\circ}$ 12.490, de 2011)

${ }^{24}$ EPE - EMPRESA DE PESQUISA ENERGÉTICA BRASILEIRA. Balanço energético nacional 2015: ano base 2014. Rio de Janeiro : EPE, 2015. 
XVIII - mitigar as emissões de gases causadores de efeito estufa e de poluentes nos setores de energia e de transportes, inclusive com o uso de biocombustíveis. (Incluído pela Lei $\mathrm{n}^{\circ} 12.490$, de 2011)

Art. $6^{\circ}$ Para os fins desta Lei e de sua regulamentação, ficam estabelecidas as seguintes definições:

$[\ldots]$

XXIV - Biocombustível: combustível derivado de biomassa renovável para uso em motores a combustão interna ou, conforme regulamento, para outro tipo de geração de energia, que possa substituir parcial ou totalmente combustíveis de origem fóssil; (Incluído pela Lei $n^{\circ} 11.097$, de 2005)

XXIV - Biocombustível: substância derivada de biomassa renovável, tal como biodiesel, etanol e outras substâncias estabelecidas em regulamento da ANP, que pode ser empregada diretamente ou mediante alterações em motores a combustão interna ou para outro tipo de geração de energia, podendo substituir parcial ou totalmente combustíveis de origem fóssil; (Redação dada pela Lei $n^{\circ}$ 12.490, de 2011)

XXV - Biodiesel: biocombustível derivado de biomassa renovável para uso em motores a combustão interna com ignição por compressão ou, conforme regulamento, para geração de outro tipo de energia, que possa substituir parcial ou totalmente combustíveis de origem fóssil. (Incluído pela Lei $\mathrm{n}^{\circ} 11.097$, de 2005)

$[\ldots]$

XXVIII - Indústria de Biocombustível: conjunto de atividades econômicas relacionadas com produção, importação, exportação, transferência, transporte, armazenagem, comercialização, distribuição, avaliação de conformidade e certificação de qualidade de biocombustíveis; (Redação dada pela Lei $n^{\circ} 12.490$, de 2011)

Neste mesmo contexto, pode-se verificar a importância da Agência Nacional do Petróleo, Gás Natural e Biocombustíveis (ANP) no papel de incentivo e regulação do mercado de biocombustíveis:

Art. 68-A. Qualquer empresa ou consórcio de empresas constituídas sob as leis brasileiras com sede e administração no País poderá obter autorização da ANP para exercer as atividades econômicas da indústria de biocombustíveis. (Incluído pela Lei $\mathrm{n}^{\circ} 12.490$, de 2011)

[...]

§ 60 Não são sujeitas à regulação e à autorização pela ANP a produção agrícola, a fabricação de produtos agropecuários e alimentícios e a geração de energia elétrica, quando vinculadas ao estabelecimento no qual se construirá, modificará ou ampliará a unidade de produção de biocombustível. (Incluído pela Lei $\mathrm{n}^{\circ}$ 12.490, de 2011) (BRASIL, 1997).

\footnotetext{
${ }^{25}$ BRASIL. Lei $\mathrm{n}^{\circ} 12.490$, de 16 de setembro de 2011. Altera as Leis nos 9.478 , de 6 de agosto de 1997 , e 9.847, de 26 de outubro de 1999, que dispõem sobre a política e a fiscalização das atividades relativas ao abastecimento nacional de combustíveis e dá outras providências. Diário Oficial da República Federativa do Brasil. Brasília, DF, 19 set. 2011. Disponível em: <http://www.planalto.gov.br/CCIVIL_03/_Ato20112014/2011/Lei/L12490.htm>. Acesso em: 9 jun. 2015.
} 
Art. 10 A fiscalização das atividades relativas às indústrias do petróleo e dos biocombustíveis e ao abastecimento nacional de combustíveis, bem como do adequado funcionamento do Sistema Nacional de Estoques de Combustíveis e do cumprimento do Plano Anual de Estoques Estratégicos de Combustíveis, de que trata a Lei no 9.478, de 6 de agosto de 1997, será realizada pela Agência Nacional do Petróleo, Gás Natural e Biocombustíveis (ANP) ou, mediante convênios por ela celebrados, por órgãos da administração pública direta e indireta da União, dos Estados, do Distrito Federal e dos Municípios. (Incluído pela Lei ${ }^{\circ} 12.490$, de 2011).

§ 100 abastecimento nacional de combustíveis é considerado de utilidade pública e abrange as seguintes atividades:

II - produção, importação, exportação, transporte, transferência, armazenagem, estocagem, distribuição, revenda e comercialização de biocombustíveis, assim como avaliação de conformidade e certificação de sua qualidade; (Incluído pela Lei $\mathrm{n}^{\circ} 12.490$, de 2011$)^{26}$.

Para completar as mudanças normativas, em 2014 sobreveio nova alteração legislativa para aumentar a produção do biodiesel, por meio do aumento do percentual de mistura obrigatória ao diesel comum, bem como para fomentar essa produção por meio da agricultura familiar. Importante frisar que todas as alterações normativas do percentual de biodiesel se deram por meio de conversão de medidas provisórias em lei, sendo que inúmeros dispositivos legais foram exaustivamente modificados ao longo do tempo, conforme o momento políticoeconômico-social em que o País se encontrava:

Art. 1o Ficam estabelecidos os seguintes percentuais de adição obrigatória de biodiesel ao óleo diesel comercializado com o consumidor final, medidos em volume, em qualquer parte do território nacional:

I - 6\% (seis por cento), a partir de 10 de julho de 2014; e

II - 7\% (sete por cento), a partir de 10 de novembro de 2014.

Art. 3o 0 biodiesel necessário à adição obrigatória ao óleo diesel deverá ser fabricado preferencialmente a partir de matérias-primas produzidas pela agricultura familiar, e caberá ao Poder Executivo federal estabelecer mecanismos para assegurar sua participação prioritária na comercialização no mercado interno ${ }^{27}$.

\footnotetext{
${ }^{26}$ BRASIL. Lei $n^{\circ}$ 9.847, de 26 de outubro de 1999. Dispõe sobre a fiscalização das atividades relativas ao abastecimento nacional de combustíveis, de que trata a Lei $n^{\circ} 9.478$, de 6 de agosto de 1997, estabelece sanções administrativas e dá outras providências. Diário Oficial da República Federativa do Brasil. Brasília, DF, 27 out. 1999. Disponível em: <http://www.planalto.gov.br/CCivil_03/LEIS/L9847.htm>. Acesso em 09 jun. 2015.

${ }^{27}$ BRASIL. Lei $\mathrm{n}^{\circ} 13.033$, de 24 de setembro de 2014. Dispõe sobre a adição obrigatória de biodiesel ao óleo diesel comercializado com o consumidor final; altera as Leis nos 9.478, de 6 de agosto de 1997, e 8.723, de 28 de outubro de 1993; revoga dispositivos da Lei no 11.097, de 13 de janeiro de 2005; e dá outras providências. Diário Oficial da República Federativa do Brasil. Brasília, DF, 25 out. 2014. Disponível em: <http://www.planalto.gov.br/ccivil_03/_Ato2011-2014/2014/Lei/L13033.htm\#art6>. Acesso em 09 jun. 2015.
} 
Em 2015 houve outra medida provisória no sentido de possibilitar o aumento da porcentagem de adição obrigatória de biodiesel ao diesel comum, a qual ainda não foi convertida em lei:

Art. $2^{\circ}$ Fica criado o Conselho Nacional de Política Energética - CNPE, vinculado à Presidência da República e presidido pelo Ministro de Estado de Minas e Energia, com a atribuição de propor ao Presidente da República políticas nacionais e medidas específicas destinadas a:

$[\ldots]$

$\mathrm{XI}$ - definir diretrizes para comercialização e uso de biodiesel e estabelecer, em caráter autorizativo, quantidade superior ao percentual de adição obrigatória fixado em lei específica. (Redação dada pela Medida Provisória $\mathrm{n}^{\circ} 688$, de $2015)^{28}$.

Por fim, em 2016 houve novamente da porcentagem de adição obrigatória de biodiesel ao diesel comum, mas agora com previsões futuras de novos aumentos:

Art. 1- A Lei $n^{\circ} 13.033$, de 24 de setembro de 2014, passa a vigorar com as seguintes alterações:

"Art. $1^{\circ}$ São estabelecidos os seguintes percentuais de adição obrigatória, em volume, de biodiesel ao óleo diesel vendido ao consumidor final, em qualquer parte do território nacional:

1 - 8\% (oito por cento), em até doze meses após a data de promulgação desta Lei; II - 9\% (nove por cento), em até vinte e quatro meses após a data de promulgação desta Lei;

III - 10\% (dez por cento), em até trinta e seis meses após a data de promulgação desta Lei." (NR)

"Art. $1^{\circ}$-A. Após a realização, em até doze meses contados da promulgação desta Lei, de testes e ensaios em motores que validem a utilização da mistura, é autorizada a adição de até $10 \%$ (dez por cento), em volume, de biodiesel ao óleo diesel vendido ao consumidor final, em qualquer parte do território nacional, observado o disposto no inciso XI do art. $2^{\circ}$ da Lei $n^{\circ} 9.478$, de 6 de agosto de 1997."

"Art. $1^{\circ}$-B. Após a realização, em até trinta e seis meses contados da promulgação desta Lei, de testes e ensaios em motores que validem a utilização da mistura, é autorizada a adição de até 15\% (quinze por cento), em volume, de biodiesel ao óleo diesel vendido ao consumidor final, em qualquer parte do território nacional, observado o disposto no inciso XI do art. $2^{\circ}$ da Lei $n^{\circ} 9.478$, de 6 de agosto de 1997.

Parágrafo único. Realizados os testes previstos no caput deste artigo, é o Conselho Nacional de Política Energética - CNPE autorizado a elevar a mistura

\footnotetext{
${ }^{28}$ BRASIL. Medida provisória $n^{\circ} 688$, de 18 de agosto de 2015. Dispõe sobre a Lei no 9.478 , de 6 de agosto de 1997, que institui o Conselho Nacional de Política Energética Executivo dá outras providências. Diário Oficial da República Federativa do Brasil, Brasília, DF, 18 ago. 2015. Disponível em: <http://www.planalto.gov.br/ccivil_03/_Ato2015-2018/2015/Mpv/mpv688.htm\#art4>. Acesso em: 10 out. 2015.
} 
obrigatória de biodiesel ao óleo diesel em até 15\% (quinze por cento), em volume, em todo o território nacional."

"Art. $1^{\circ}$-C. São facultados a adição voluntária de biodiesel ao óleo diesel em quantidade superior ao percentual obrigatório e o uso voluntário da mistura no transporte público, no transporte ferroviário, na navegação interior, em equipamentos e veículos destinados à extração mineral e à geração de energia elétrica, em tratores e nos demais aparelhos automotores destinados a puxar ou arrastar maquinaria agrícola ou a executar trabalhos agrícolas, observado o disposto no inciso XI do art. $2^{\circ}$ da Lei ${ }^{\circ} 9.478$, de 6 de agosto de $1997^{\prime 29}$.

Passando para uma análise quantitativa da produção de biodiesel é possível extrair algumas constatações a respeito dos efeitos das modificações normativas citadas nesta matriz energética. Para analisar a tabela 2 a seguir é necessário entender as mudanças normativas já mencionadas no contexto anual da produção de biodiesel brasileira: a partir de 2008, a mistura de biodiesel puro ao óleo diesel passou a ser obrigatória. Entre janeiro e junho de 2008, a mistura de biodiesel puro ao óleo diesel foi de 2\%. Entre julho de 2008 e junho de 2009 foi de 3\%, entre julho e dezembro de 2009 foi de 4\%. Entre janeiro de 2010 e junho de 2014 foi de 5\%. Entre julho e outubro de 2014 o teor de mistura de biodiesel ao óleo diesel foi de 6\% e a partir de novembro de 2014 passou a ser de 7\%, em volume, conforme Lei $n^{\circ}$ 13.033/2014 (Tabela 2).

Primeiramente analisando o panorama de mudanças nos teores percentuais de mistura de biodiesel puro ao óleo diesel, pode-se concluir que essa estratégia funcionou, pois ao longo dos anos, quando houve aumento no percentual obrigatório de mistura do biodiesel, houve correspondência no aumento da produção, e isso pode ser notado após um ou dois meses após as mudanças normativas apontadas anteriormente (Tabela 2). A penúltima mudança ocorreu em novembro de 2014, com aumento para $7 \%$ na mistura e a partir de então, somente em fevereiro de 2015 que a produção não havia superado os dois milhões de barris equivalente petróleo. A partir de dezembro de 2015 a produção começou novamente a cair, quando houve nova mobilização legislativa com aprovação da atual lei sobre o assunto de adição do percentual em março de 2016, elevando o percentual para $8 \%$, podendo chegar a 15\%, nos próximos três anos, conforme Lei $n^{\circ} 13.263 / 16$. No entanto, percebe-se que os últimos dados de produção de maio de 2016 apontam novamente para uma queda, indicando certa saturação do setor produtivo e de consumo.

\footnotetext{
${ }^{29}$ BRASIL. Lei $n^{\circ} 13.263$, de 23 de março de 2016. Altera a Lei $n^{\circ} 13.033$, de 24 de setembro de 2014, para dispor sobre os percentuais de adição de biodiesel ao óleo diesel comercializado no território nacional. Diário Oficial da República Federativa do Brasil, Brasília, DF, 24 mar. 2016. Disponível em: <http://www.planalto.gov.br/ccivil_03/_Ato2015-2018/2016/Lei/L13263.htm>. Acesso em: 12 jul. 2016.
} 
Tabela 2. Produção anual e mensal de biodiesel no Brasil em barril equivalente petróleo (bep) ${ }^{30}$.

\begin{tabular}{|c|c|c|c|c|c|c|c|c|c|c|c|c|}
\hline Mês & 2005 & 2006 & 2007 & 2008 & 2009 & 2010 & 2011 & 2012 & 2013 & 2014 & 2015 & 2016 \\
\hline Jan & - & 6.822 & 108.538 & 487.121 & 573.196 & 935.326 & 1.182 .061 & 1.224 .432 & 1.436 .949 & 1.555 .647 & 2.027 .203 & 172168 \\
\hline Fev & - & 6.618 & 07.421 & 489.027 & 508.943 & 1.129 .546 & 1.121 .513 & 1.361 .467 & 1.305 .203 & 1.525 .913 & 1.926 .003 & 1.903 .61 \\
\hline Mar & 49 & 10.942 & 143.608 & 403.984 & 837.354 & 1.358 .567 & 1.481 .100 & 1.401 .211 & 1.463 .893 & 1.724 .546 & 2.047 .158 & 2.050 .112 \\
\hline $\mathrm{Abr}$ & 83 & 11.327 & 119.095 & 408.235 & 669.025 & 1.172 .985 & 1.271 .218 & 1.156 .970 & 1.608 .781 & 1.606 .456 & 2.058 .794 & 2.210 .79 \\
\hline Mai & 163 & 16.352 & 164.974 & 482.137 & 657.636 & 1.286 .110 & 1.398 .750 & 1.351 .404 & 1.560 .205 & 1.538 .582 & 2.149 .668 & 5.99 \\
\hline Jun & 145 & 41.175 & 172.290 & 651.952 & 895.385 & 1.300 .138 & 1.469 .097 & 1.363 .312 & 1.499 .982 & 1.595 .626 & 2.043 .943 & \\
\hline Jul & 46 & 21.131 & 169.501 & 683.796 & 980.507 & 1.315 .959 & 1.585 .347 & 1.461 .279 & 1.653 .695 & 1.922 .050 & 2.163 .899 & \\
\hline Ago & 362 & & 278.875 & 694.887 & 1.059 .994 & 1.466 .476 & 1.572 .895 & 1.614 .079 & 1.570 .841 & 1.995 .392 & 2.182 .576 & \\
\hline Set & 13 & 42.729 & 291.909 & 839.047 & 1.018 .453 & 1.395 .601 & 1.484 .315 & 1.600 .227 & 1.603 .215 & 1.983 .546 & 2.095 .983 & \\
\hline Out & 215 & 54.441 & 340.093 & 804.529 & 994.806 & 1.268 .133 & 1.509 .143 & 1.594 .984 & 1.763 .581 & 2.040 .247 & 2.278 .547 & \\
\hline Nov & 1.785 & 101.662 & 357.805 & 748.684 & 1.054 .323 & 1.318 .712 & 1.504 .726 & 1.556 .314 & 1.682 .273 & 2.008 .679 & 2.059 .657 & \\
\hline Dez & 1.809 & 92.185 & 310.956 & 710.864 & 954.375 & 1.191 .759 & 1.375 .824 & 1.554 .037 & 1.359 .927 & 2.213 .816 & 1.944 .600 & \\
\hline & 4.670 & 1.147 & & & & & & & & & & \\
\hline Média & 467 & 36.479 & 13.755 & 617.022 & 850.333 & 1.261 .609 & 1.412 .999 & 1.436 .643 & 1.542 .379 & 1.809 .208 & 2.081 .503 & 1.994 .44 \\
\hline
\end{tabular}

FONTE: (ANP, 2016).

O problema dessa estratégia é que ela fornece resultados em curto prazo, visto que há limitação técnica para adição de biodiesel no óleo diesel, sendo que esses aumentos devem vir acompanhados de estudos técnicos que demonstrem a eficiência e o não comprometimento da parte mecânica dos veículos que utilizam a mistura como combustível. Além disso, essa estratégia em longo prazo não tem tendência linear, ou seja, os resultados dos aumentos produtivos de biodiesel com aumento do percentual da mistura ao diesel tendem a ser cada vez menores (tendência quadrática).

Visto que a produção de biodiesel realmente se iniciou em 2005, ainda atualmente essa estratégia vem surtindo o efeito desejável pelo governo brasileiro (Figura 1a).

${ }^{30}$ ANP - AGÊNCIA NACIONAL DO PETRÓLEO, GÁS NATURAL E BIOCOMBUSTÍVEIS. Produção de biodiesel. 2015b. Disponível em: <http://dados.gov.br/dataset/biodiesel-producao>. Acesso em 05 dez. 2015. 
a)

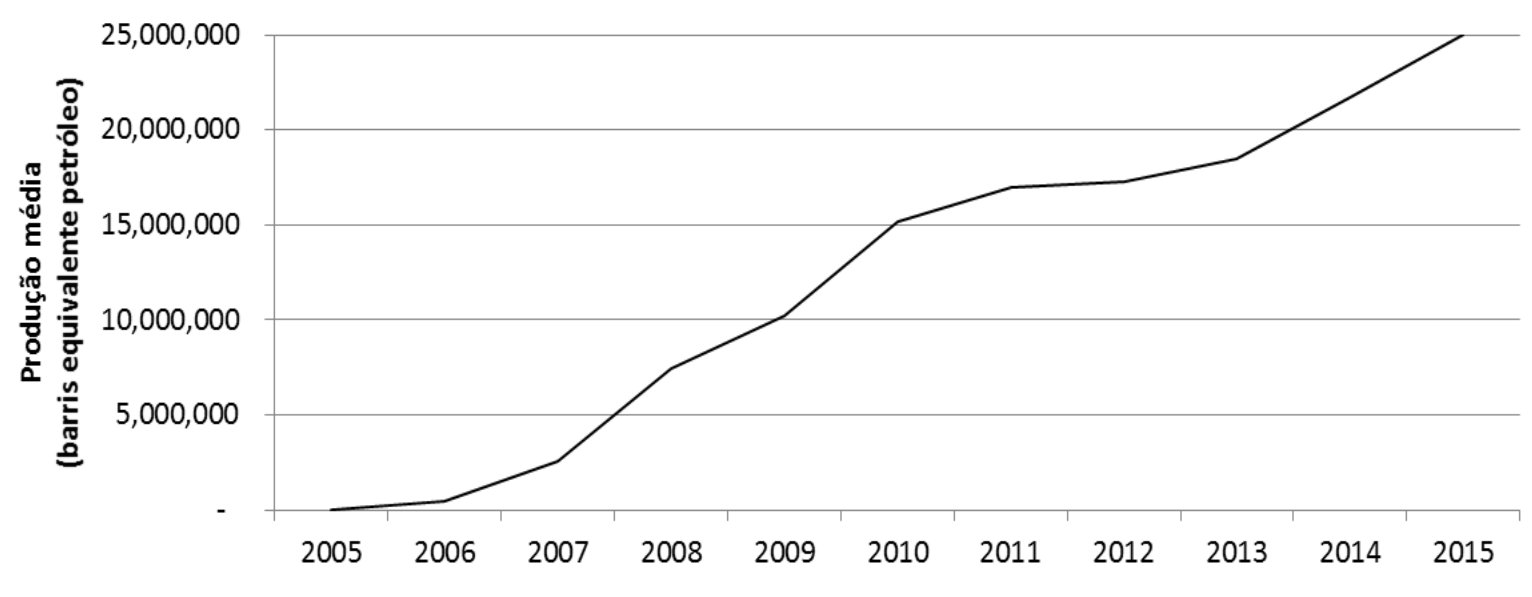

b)

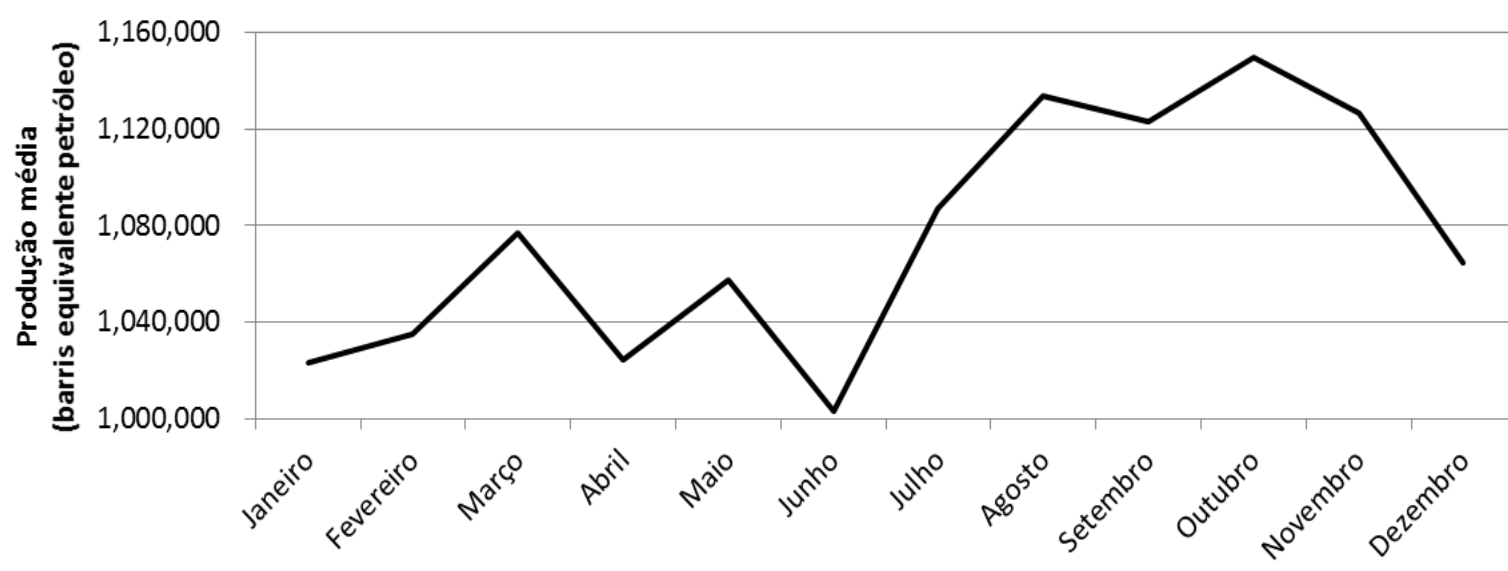

FONTE: (ANP, 2016).

Figura 1: Produção de biodiesel no Brasil, sendo: (a) Produção acumulada anual; (b) Produção média mensal ${ }^{31}$.

Analisando a produção média mensal ao longo dos anos, a Figura 1b corrobora e atesta os resultados das Tabelas 2 e 3, à medida que há diversidade mensal na produção de biodiesel, justamente porque o biodiesel possui como principais matérias-primas, culturas agrícolas: a soja é a principal matéria-prima utilizada na sua produção, como será visto na próxima seção. A partir de outubro começa a diminuir a produção, porque é o período que inicia o plantio da cultura no Brasil, e a partir de maio tende a aumentar a produção porque é o período de colheita.

${ }^{31}$ ANP - AGÊNCIA NACIONAL DO PETRÓLEO, GÁS NATURAL E BIOCOMBUSTÍVEIS. Produção de biodiesel. 2015b. Disponível em: <http://dados.gov.br/dataset/biodiesel-producao>. Acesso em 05 dez. 2015. 
A Figura 1b demonstra que a produção de biodiesel não pode se basear em apenas uma matéria-prima, pois isto contrasta com um dos princípios fundantes do conceito de sustentabilidade, a diversidade das fontes energéticas. Em conformidade a este princípio da sustentabilidade, o ideal seria que a produção mensal fosse constante para evitar a ociosidade nas usinas produtoras. Para tanto, é imperativo que a produção não esteja ancorada em apenas uma matéria-prima. Outra fragilidade brasileira que os dados tornam visível é a capacidade limitada de armazenagem estática de grãos do País, mas esta análise escapa ao escopo deste artigo.

\section{NORMATIVAS DO BIODIESEL E AGRICULTURA FAMILIAR BRASILEIRA}

Outra análise muito importante a ser feita e talvez a mais importante é o reflexo do campo jurídico na produção de biodiesel na agricultura familiar brasileira, porque como já visto, o PNPB tem como um dos seus pilares o biodiesel como instrumento para fortalecimento e melhoria das condições de vida da agricultura familiar no Brasil ${ }^{32}$.

A despeito da produção total de biodiesel ser crescente ao longo dos anos analisados (Tabela 2), o mesmo não ocorreu com a produção da agricultura familiar brasileira. Todas as mudanças normativas e regulamentares (2005, 2011, 2014 e 2015) fizeram com que a produção de biodiesel atingisse seu ápice nos anos de 2010 e 2011. Até o período de 2010, a produção da agricultura familiar somente crescia, com vários incentivos públicos. No entanto, tal situação não perdurou muito como demonstrado pelo levantamento da Companhia Brasileira de Abastecimento (CONAB) que divulga estudos técnicos sobre as principais oleaginosas produzidas no Brasil (Tabela 3).

32 MDA - MINISTÉRIO DO DESENVOLVIMENTO AGRÁRIO. Programa Nacional de Produção e Uso de Biodiesel: inclusão social e desenvolvimento territorial. Brasília: MDA, 2010. 
ISSN 1981-3694

(DOI): $10.5902 / 1981369421066$

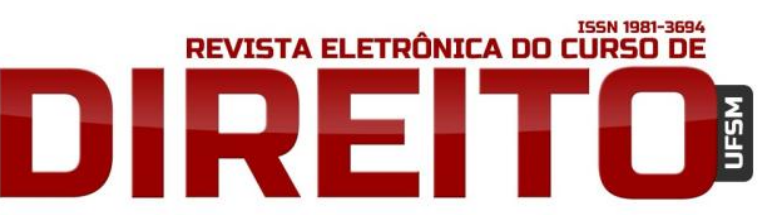

CAMPO JURÍDICO E POLÍTICAS DO BIODIESEL: AGRICULTURA FAMILIAR E EFETIVIDADE DA NORMA

BRUNO CÉSAR GURSKI JOSÉ EDMILSON SOUZA LIMA

Tabela 3. Produção total anual das principais oleaginosas cultivadas no Brasil (em mil toneladas) $)^{33}$

\begin{tabular}{lrrrrrrrrrr}
\hline $\begin{array}{c}\text { Cultura/ } \\
\text { Ano }\end{array}$ & $2005 / 06$ & $2006 / 07$ & $2007 / 08$ & $2008 / 09$ & $2009 / 10$ & $2010 / 11$ & $2011 / 12$ & $2012 / 13$ & $2013 / 14$ & $2014 / 15$ \\
\hline Algodão & 1.686 & 2.384 & 2.505 & 1.891 & 1.843 & 3.229 & 3.019 & 2.019 & 2.671 & 2.360 \\
Canola & 0 & 0 & 0 & 0 & 42 & 70 & 52 & 61 & 36 & 54 \\
Girassol & 94 & 106 & 147 & 109 & 81 & 83 & 116 & 110 & 233 & 153 \\
Mamona & 104 & 94 & 123 & 93 & 101 & 141 & 25 & 16 & 45 & 47 \\
Soja & 55.027 & 58.392 & 60.018 & 57.166 & 68.688 & 75.324 & 66.383 & 81.499 & 86.121 & 96.243 \\
\hline Brasil & 122.531 & 131.751 & 144.137 & 135.135 & 149.255 & 162.803 & 166.172 & 188.658 & 193.622 & 208.536 \\
\hline
\end{tabular}

FONTE: (CONAB, 2015).

A CONAB não considera relevantes, do ponto de vista técnico e numérico, culturas como pinhão manso, gergelim e dendê, por isso, não há levantamento de dados periódicos sobre a produção dessas culturas. Com exceção da soja, é possível verificar um comportamento bem distinto na produção das oleaginosas brasileiras ao longo dos anos, há um crescimento até atingir um máximo, seguida de queda nos últimos dois anos, resultado que contrasta com a teleologia normativa. Além disso, há outros dados preocupantes: a diversidade das fontes da matriz energética brasileira (Tabela 1) não acompanha as fontes para produção de biodiesel no Brasil, pois apenas duas matérias-primas são responsáveis por mais de 95\% da produção (Tabela 4). Conforme vimos na seção 3 , esta pouca diversidade das fontes é um indicador contrário ao princípio da sustentabilidade.

Tabela 4. Participação anual das matérias primas na produção brasileira de biodiesel ${ }^{34}$

\begin{tabular}{lcccccccc}
\hline Matéria-prima/Ano & $\mathbf{2 0 0 8}$ & $\mathbf{2 0 0 9}$ & $\mathbf{2 0 1 0}$ & $\mathbf{2 0 1 1}$ & $\mathbf{2 0 1 2}$ & $\mathbf{2 0 1 3}$ & $\mathbf{2 0 1 4}$ & $\mathbf{2 0 1 5}$ \\
\hline Óleo de soja & $69 \%$ & $78 \%$ & $82 \%$ & $81 \%$ & $75 \%$ & $73 \%$ & $75 \%$ & $\mathbf{7 8 \%}$ \\
Gorduras animais & $18 \%$ & $16 \%$ & $14 \%$ & $14 \%$ & $18 \%$ & $21 \%$ & $21 \%$ & $19 \%$ \\
Óleo de algodão & $2 \%$ & $4 \%$ & $2 \%$ & $3 \%$ & $5 \%$ & $2 \%$ & $2 \%$ & $1 \%$ \\
Óleo de fritura usado & $0 \%$ & $0 \%$ & $0 \%$ & $0 \%$ & $1 \%$ & $1 \%$ & $1 \%$ & $0 \%$ \\
Outras & $12 \%$ & $2 \%$ & $1 \%$ & $2 \%$ & $2 \%$ & $2 \%$ & $1 \%$ & $1 \%$ \\
\hline
\end{tabular}

FONTE: (ABIOVE, 2015).

${ }^{33}$ CONAB - COMPANHIA NACIONAL DE ABASTECIMENTO. Séries históricas de área plantada, produtividade e produção, relativas às safras 1976/77 a 2014/15. Brasília: CONAB, 2015. Disponível em: <http://www.conab.gov.br/conteudos.php?a=1252\&\&Pagina_objcmsconteudos=2\#A_objcmsconteudos>. Acesso em 05 dez. 2015.

${ }^{34}$ ABIOVE - ASSOCIAÇÃOO BRASILEIRA INDÚSTRIAS ÓLEOS VEGETAIS. Biodiesel: matérias-primas para produção. $2015 . \quad$ Disponível em: <http://www.abiove.org.br/site/index.php?page=estatistica\&area=NCOyLTE=> Acesso em 05 dez. 2015. 
Os objetivos principais na criação do Programa Nacional de Produção e Uso de Biodiesel (PNPB) eram a diversificação das matérias-primas para inclusão social, geração de emprego e distribuição de renda entre agricultores familiares produtores de matéria prima. Em 2008, havia certa divisão e participação de outras matérias-primas na produção de biodiesel, como a mamona, pinhão manso, palma, girassol, entre outros. No entanto, a partir de 2009 a participação dessas culturas na diversificação de matérias-primas caiu drasticamente, sendo que a principal matéria-prima responsável pela produção de biodiesel no Brasil sempre foi uma commodity agrícola, que em tese, não é produzida pela agricultura familiar brasileira ${ }^{35}$.

Atualmente, essa situação é heterogênea quando analisada regionalmente no País (Tabela 5). Regiões em que há maior quantidade de pequenas propriedades rurais há maior diversificação na matéria-prima, como nas regiões Sul e Sudeste, mas em regiões com predomínio de grandes propriedades há menor diversificação, como Norte e Centro-Oeste. A região Nordeste, onde houve maiores esforços do PNPB para a diversificação das matériasprimas, também não apresenta um panorama justificável de diversificação das culturas com potencial energético renovável.

Tabela 5. Participação das matérias-primas na produção regional brasileira de biodiesel em novembro de $2015^{36}$

\begin{tabular}{lccccc}
\hline \multicolumn{1}{c}{ Matéria-prima } & Norte & Nordeste & Centro-Oeste & Sudeste & Sul \\
\hline Óleo de soja & $99,55 \%$ & $45,16 \%$ & $78,66 \%$ & $34,68 \%$ & $70,27 \%$ \\
Gordura bovina & $0,45 \%$ & $35,97 \%$ & $15,39 \%$ & $52,01 \%$ & $25,68 \%$ \\
Óleo de algodão & & $14,52 \%$ & $4,71 \%$ & $2,66 \%$ & \\
Outros materiais graxos & & $4,35 \%$ & $0,71 \%$ & $6,54 \%$ & $1,21 \%$ \\
Óleo de fritura usado & & & $0,39 \%$ & $4,11 \%$ & $0,29 \%$ \\
Gordura suína & & $0,14 \%$ & & $2,30 \%$ \\
Gordura de frango & & $0,01 \%$ & & $0,25 \%$ \\
\hline
\end{tabular}

FONTE: (ANP, 2015a).

35 MDA - MINISTÉRIO DO DESENVOLVIMENTO AGRÁRIO. Programa Nacional de Produção e Uso de Biodiesel: inclusão social e desenvolvimento territorial. Brasília: MDA, 2010.

${ }^{36}$ ANP - AGÊNCIA NACIONAL DO PETRÓLEO, GÁS NATURAL E BIOCOMBUSTíVEIS. Boletim mensal do biodiesel. Novembro, 2015a. Disponível em: <http://www.anp.gov.br/?pg=78672\&m=\&t1=\&t2=\&t3=\&t4=\&ar=\&ps=\&1449790252217>. Acesso em: 05 dez. 2015. 
ISSN 1981-3694

(DOI): $10.5902 / 1981369421066$

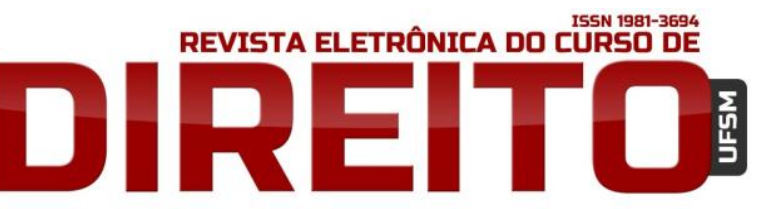

CAMPO JURÍDICO E POLÍTICAS DO BIODIESEL: AGRICULTURA FAMILIAR E EFETIVIDADE DA NORMA

BRUNO CÉSAR GURSK JOSÉ EDMILSON SOUZA LIMA

Como conclusão dessa análise relacionando biodiesel e agricultura familiar no contexto brasileiro, pode-se afirmar que a matriz energética do biodiesel iniciou com grande diversidade de matérias-primas na sua produção, um dos principais objetivos do PNPB. Contudo, essa diversificação em vez de aumentar ou se manter estável, diminuiu de forma significativa, solidificando-se atualmente em apenas duas matrizes principais, quais sejam uma commodity agrícola (a soja) e outra que é uma fonte secundária de outra commodity, a carne bovina (o boi gordo).

Vimos que as principais mudanças normativas ocorreram no ano de 2011 e que, apesar disso, os anos de 2012 e 2013 são especialmente importantes porque marcam a diferença na tendência da produção de biodiesel pela agricultura familiar brasileira (Tabela 6), pois todas as variáveis analisadas diminuíram depois desses anos, inclusive a produção. De certo modo, a despeito da redução indicada pelas tabelas justificar as mudanças normativas impondo aumento do percentual de biodiesel ao diesel comum a partir de 2014, este conjunto de normas não favoreceu a produção brasileira como um todo, não alcançou seus principais objetivos, os agricultores familiares (Tabela 7).

Tabela 6. Caracterização da produção anual de biodiesel pela agricultura familiar brasileira ${ }^{37}$

\begin{tabular}{ccccc}
\hline Ano & $\begin{array}{c}\text { Agricultores } \\
\text { familiares produtores }\end{array}$ & $\begin{array}{c}\text { Unidades com selo } \\
\text { combustivel social }\end{array}$ & $\begin{array}{c}\text { Aquisições da } \\
\text { AF (R\$ - em } \\
\text { milhões) }\end{array}$ & $\begin{array}{c}\text { Apoio a projetos } \\
\text { (R\$) }\end{array}$ \\
\hline 2005 & 16.328 & 3 & - & $951.111,83$ \\
2006 & 40.595 & 9 & 68,57 & $2.846 .962,98$ \\
2007 & 36.746 & 26 & 117,50 & $3.313 .723,39$ \\
2008 & 28.656 & 30 & 276,53 & $7.957 .071,19$ \\
2009 & 51.047 & 32 & 677,35 & $3.974 .116,62$ \\
2010 & 100.371 & 32 & $1.058,70$ & $7.163 .895,05$ \\
2011 & 104.295 & 37 & $1.519,16$ & $8.272 .537,47$ \\
2012 & 92.673 & 40 & $2.110,49$ & $8.493 .810,32$ \\
2013 & 83.754 & 45 & $2.855,19$ & $1.493 .355,00$ \\
2014 & 44.304 & 41 & $2.662,00$ & $1.930 .743,75$ \\
\hline
\end{tabular}

FONTE: (MDA, 2015).

${ }^{37}$ MDA - MINISTÉRIO DO DESENVOLVIMENTO AGRÁRIO. Informações do MDA e do INCRA. Brasília: MDA, 2015. 
ISSN 1981-3694

(DOI): $10.5902 / 1981369421066$

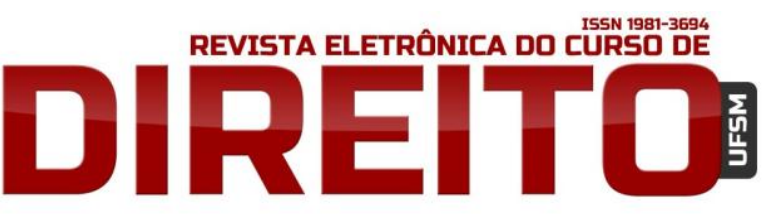

CAMPO JURÍDICO E POLÍTICAS DO BIODIESEL: AGRICULTURA FAMILIAR E EFETIVIDADE DA NORMA

BRUNO CÉSAR GURSKI JOSÉ EDMILSON SOUZA LIMA

Tabela 7. Produção anual total de biodiesel no Brasil e produção pela agricultura familiar brasileira em barril equivalente petróleo (bep) ${ }^{38}$

\begin{tabular}{cccc}
\hline Ano & Produção Total (bep) & Produção Agricultura Familiar (bep) & Diferença (bep) \\
\hline 2005 & 4.670 & 4.630 & 40 \\
2006 & 437.749 & 434.009 & 3.739 \\
2007 & 2.565 .064 & 2.543 .154 & 21.910 \\
2008 & 7.404 .263 & 7.341 .017 & 63.246 \\
2009 & 10.203 .997 & 10.116 .836 & 87.161 \\
2010 & 15.139 .312 & 15.009 .995 & 129.317 \\
2011 & 16.955 .989 & 16.811 .154 & 144.835 \\
2012 & 17.239 .715 & 17.092 .457 & 147.258 \\
2013 & 18.508 .546 & 18.350 .450 & 158.096 \\
2014 & 21.695 .452 & 17.272 .788 & 4.422 .665 \\
\hline
\end{tabular}

FONTE: (MDA, 2015).

Essa queda na produção de biodiesel pela agricultura familiar tem reflexo direto no setor econômico. Nos últimos anos, a Petrobras Biocombustíveis, principal empresa brasileira responsável pela produção de biodiesel no País, teve prejuízo no resultado financeiro líquido de 2013 e 2014 de R\$ 293.515.000,00 e 228.859.000,00, respectivamente ${ }^{39}$. Esta constatação é ao mesmo tempo interessante e contraditória: as mudanças normativas tiveram reflexo direto no aumento da produção total brasileira de biodiesel (Tabela 2), mas não houve, em termos quantitativos e qualitativos, o reflexo esperado na produção de biodiesel pela agricultura familiar. Ao contrário, muitas situações até se agravaram, como por exemplo, a baixa diversificação no uso de matérias-primas para produção de biodiesel que, ao se afastar do princípio da sustentabilidade (a diversificação), ocasiona o aumento das desigualdades sociais entre as regiões brasileiras.

A norma não conseguiu subsidiar e garantir as melhorias propostas para a agricultura familiar e, neste sentido, com vistas a avançar a análise, é imperativo tentar compreender a relação entre o campo jurídico e outros campos de conhecimento. Na análise sistemática das cadeias produtivas das matérias-primas do biodiesel na agricultura familiar, percebeu-se a escassez de material técnico-científico sobre o assunto. Apesar disso, alguns autores analisaram essas cadeias produtivas a fim de refletir sobre a inclusão social da agricultura familiar

\footnotetext{
${ }^{38}$ MDA - MINISTÉRIO DO DESENVOLVIMENTO AGRÁRIO. Informações do MDA e do INCRA. Brasília: MDA, 2015.

39 PETROBRAS. Relatório de administração e balanço contábil de 2014. Rio de Janeiro: Petrobras Biocombustível S.A. 2015.
} 
principalmente na região semiárida nordestina ${ }^{40}$. Esses autores levantaram uma série de fatores, sobretudo econômicos e agronômicos, que determinaram o declínio de várias cadeias produtivas, como por exemplo: quebra de contratos das usinas de biodiesel com os produtores rurais pela falta de recolhimento da produção ou dificuldade de comercialização (ação de atravessadores), assistência técnica inexistente ou desqualificada, tecnologia produtiva inadequada, degradação ambiental e, por fim, incentivos aos agricultores para eliminar o plantio de subsistência, somente para cultivar plantas oleaginosas produtoras de biodiesel, afetando diretamente a segurança e soberania alimentar da região.

Esses obstáculos forçaram o governo a implementar ações e políticas públicas para reverter tal situação. As principais ações foram a criação da Petrobrás Biocombustíveis em 2008 e atuação da ANP para facilitar a comercialização por meio dos leilões públicos para compra de biodiesel, o que estimulou o aumento da eficiência das cadeias produtivas. Contudo, vale relembrar que atualmente a produção de biodiesel pela agricultura familiar vem diminuindo a cada ano (Tabelas 6 e 7).

Sanches enumera pelo menos quatro razões para o insucesso na produção do biodiesel pela agricultura familiar brasileira: dificuldade de expansão agrícola, com fornecimento seguro e adequado do biodiesel sem comprometer a segurança alimentar; uso adequado de tecnologia para otimização da cadeia produtiva familiar do biodiesel; expansão na exploração do petróleo, inclusive com o descobrimento do Pré-Sal e desinteresse nas energias alternativas ${ }^{41}$. Já Obermaier e Rovere afirmam que o PNPB limita-se em tratar de barreiras técnicas ou políticas em um contexto específico da sua atuação, mas não em fatores como as causas estruturais da pobreza, apoio político para a expansão do agronegócio, ou a globalização ${ }^{42}$.

\footnotetext{
${ }^{40}$ Neste sentido, destacam-se os seguintes autores e suas respectivas obras: HALL, J.; MATOS, S.; SEVERINO, L. Brazilian biofuels and social exclusion: established and concentrated ethanol. Journal of Cleaner Production, 17:577-585, 2009. CÉSAR, A.D.S.; BATALHA, M.O. Biodiesel production from castor oil in Brazil: a difficult reality. Energy Policy, 38: 4031-4039, 2010. ZAPATA, C.; VASQUEZ-BRUST, D.; PLAZAÚBEDA, J. Productive inclusion of smallholder farmers in Brazil's biodiesel value chain: programme design, institutional incentives and stakeholder constraints. Working Paper, 73, Brasília: International Policy Centre for Inclusive Growth (IPC), UNDP, 2010. OBERMAIER, M.; ROVERE, E. L. Vulnerabilidade e resiliência socioambiental no contexto da mudança climática: o caso do Programa Nacional de Produção e Uso de Biodiesel (PNPB). Parcerias Estratégicas, v.16, n.33, p. 109-134, 2011.

${ }^{41}$ SANCHES, L. A. U. Curso de direito da energia: da história, tomo I. São Paulo: Instituto Geodireito, 2011, p. 400.

42 OBERMAIER, M.; ROVERE, E. L. Vulnerabilidade e resiliência socioambiental no contexto da mudança climática: o caso do Programa Nacional de Produção e Uso de Biodiesel (PNPB). Parcerias Estratégicas, v.16, n.33, p. 109-134, 2011.
} 
Como foi verificado na normativa sobre a produção de biodiesel pela agricultura familiar brasileira, a política energética nacional possui forte caráter econômico-social, mas não exerceu os efeitos pretendidos pelo legislador para essa classe social dentro de cada contexto social do País. A análise normativa apenas desse setor específico não ofereceu elementos suficientes para a compreensão acerca dos processos de extinção das cadeias produtivas familiares do biodiesel. A norma em si, como instrumento de incentivo à produção de biodiesel pela agricultura familiar revelou ser extremamente perigosa, no sentido de que seu uso inadequado pode destruir uma economia local ou pôr em situação de risco a soberania alimentar de determinada região. Neste sentido, Romeiro, ao reivindicar um conceito de desenvolvimento sustentável centrado no local de interesse, destaca a necessidade de políticas públicas específicas que estejam em sintonia com as particularidades socioeconômicas e ambientais brasileiras ${ }^{43}$. A explicação para essa problemática pode estar presente na própria norma, mas em aspectos não jurídicos como seu processo de elaboração.

\section{ASPECTOS NÃO JURÍDICOS DA NORMA SOBRE BIODIESEL}

Como visto anteriormente, a análise da norma em si como instrumento de concretização dos objetivos institucionais associados às políticas de produção de biodiesel pela agricultura familiar no Brasil foi insuficiente. Faz-se necessário entender os interesses políticos, sociais e econômicos presentes no processo legislativo (o que poderíamos chamar de "sentidos políticos da formulação e reformulação das leis”). O processo legislativo deriva de relações de força e interesses entre diversos atores sociais pelo monopólio do processo de formulação das leis. Esse processo complexo já foi alvo de diversos estudos e permeia todos os segmentos da sociedade brasileira. Conforme pondera Silva:

O processo legislativo é formal em dois sentidos. Primeiro, porque está subordinado a formalidades previstas na Constituição e nos regimentos internos das Câmaras Legislativas. Segundo, porque é representação (ou deve ser) do que, efetivamente, se dá no entrechoque dos interesses sociais. Por isso, quanto mais divergentes são os interesses das classes sociais, quanto mais são aguçadas as contradições do sistema social vigente, tanto mais acirrados são os debates e as lutas no processo de formação das leis, já que estas vão estabelecer os limites dos interesses em jogo, tutelando uns e coibindo outros. Daí também a luta prévia relativa a composição dos órgãos incumbidos da função legislativa, pois

43 ROMEIRO, A. R. Desenvolvimento sustentável: uma perspectiva econômico-ecológica. Estudos Avançados, v. 26, n. 74, 2012. 
que, no regime de representação popular e decisão por maioria, os titulares dos interesses que conseguirem maior representação têm a possibilidade de domínio. Essa luta prévia se traduz no procurar evitar-se que os interesses dominados, ou que se quer dominar, venham a participar da legislação ${ }^{44}$.

No que tange a questão do biodiesel no Brasil há vários efeitos desses jogos de força política e das relações de poder exercidos na formulação e reformulação das normas relativas à produção de biocombustíveis pelos diversos setores da sociedade, os quais fornecem indicativos originais para o entendimento de alguns dos insucessos das políticas de biodiesel no Brasil, sobretudo pela agricultura familiar.

Em levantamento realizado pelo Correio Brasiliense em 2011, considerando os gastos de campanha declarados ao Tribunal Superior Eleitoral, concluiu-se que determinados deputados e senadores, considerados da frente ruralista, foram financiados em pelo menos R\$ 6,46 milhões por empresas ligadas ao agronegócio. Dentre estes, fabricantes de biodiesel figuram entre os financiadores. Demonstrou-se que esse grupo parlamentar, que defende os interesses do agronegócio, cresce e acumula poder para influir ainda mais nos projetos com chance de serem votados nas próximas legislaturas ${ }^{45}$. Como preceitua o estatuto da atual Frente Parlamentar da Agropecuária:

Art. $1^{\circ}$ A Frente Parlamentar da Agropecuária (FPA), é uma entidade associativa que defende interesses comuns, constituída por representantes de todas as correntes de opinião política do Congresso Nacional e tem como objetivo estimular a ampliação de políticas públicas para o desenvolvimento do agronegócio nacional ${ }^{46}$.

Em certa medida, os interesses da Frente Parlamentar da Agropecuária são recíprocos aos da Frente Parlamentar do Biodiesel na atual legislatura na Câmara dos Deputados em Brasília, visto que muitos dos deputados figuram em ambas as frentes (Tabela 8).

\footnotetext{
44 SILVA, J. A. Princípios do processo de formação das leis no direito constitucional. São Paulo: Editora Revista dos Tribunais, 1964, p. 27-28.

${ }^{45}$ SASSINI, V. Pauta sob pressão da bancada ruralista. Correio Braziliense, Caderno de Política. Edição 07 fev. 2011, p. 4.4 Disponível <http://www2.senado.leg.br/bdsf/bitstream/handle/id/48454/noticia.htm?sequence=1 >. Acesso em: 11 jul. 2016.

46 BRASIL. Estatuto da Frente Parlamentar da Agropecuária. Brasília, 2014. Disponível em: <http://www.fpagropecuaria.org.br/estatuto>. Acesso em: 12 jul. 2016.
} 
Tabela 8. Quantidade de deputados federais participantes das frentes parlamentares que abordam assuntos sobre o biodiesel no Brasil ${ }^{47}$.

\begin{tabular}{ccc}
\hline Frente Parlamentar & Total de Integrantes & Integrantes de ambas as frentes \\
\hline Agropecuária & 191 & \multirow{2}{*}{95} \\
Biodiesel & 231 & \\
\hline
\end{tabular}

FONTE: (BRASIL, 2016a).

Diversos estudos demonstraram que a direção inicial do PNPB vem sendo substituída por uma lógica de produção agrícola mais aderente aos ideais capitalistas da agroindústria (em que a soja tem papel predominante) do que aos interesses e à lógica da agricultura familiar brasileira $^{48}$. Esse aspecto pode também ser notado quando se analisa a participação das matérias-primas na produção brasileira de biodiesel (Tabelas 4 e 5), e contrasta negativamente com a teoria kelseniana que preceitua a teleologia da norma apenas do ponto de vista da legalidade do processo legislativo de sua elaboração.

A Resolução ANP, $n^{\circ}$ 30/2013, estabelece atualmente os requisitos técnicos para construção de novas unidades, ampliação de capacidade, modificação de plantas existentes e operação de plantas produtoras de biodiesel. Além de todos os requisitos exigidos para ser um produtor de biodiesel, a comercialização do produto depende de prévia aprovação da qualidade do combustível, feita por meio do envio do certificado da qualidade do produto, contendo todas as exigências estabelecidas na seção da Certificação do Biodiesel da Resolução ANP $n^{\circ} 14$, de 11 de maio de 2012.

Em nenhuma das resoluções da ANP há flexibilização dos requisitos exigidos para produção e comercialização do biodiesel por agricultores familiares. Para a agência, produtor de biodiesel somente pode ser empresa, cooperativa ou consórcio autorizado pela própria ANP. Em muitos casos a ANP até limita a comercialização entre produtores de biodiesel:

Art. 18. Fica condicionada à prévia aprovação da ANP, a comercialização de Biodiesel e de alquil ésteres de ácido carboxílico de cadeia longa entre Produtores de Biodiesel.

47 BRASIL. Frentes Parlamentares da Câmara dos Deputados. 2016a. Disponível em: <http://www.camara.leg.br/internet/deputado/Frente_Parlamentar.asp>. Acesso em: 12 jul. 2016.

${ }^{48}$ ABREU, Y. V. Biodiesel no Brasil em três hiatos: selo combustível social, empresas e leilões, 2005 a 2012. Málaga: Universidade de Málaga, 2012.; SILVA, J. A. Avaliação do Programa Nacional de Produção e Uso do Biodiesel no Brasil - PNPB. Política Agrícola, v. 22, n. 3, 2013.; e, SOUZA, J. D. F.; PAULILLO, L. F. 0 biodiesel brasileiro: matérias-primas, agroindústrias e a agricultura familiar. $48^{\circ}$ Congresso da Sociedade Brasileira de Economia, Administração e Sociologia Rural. Campo Grande, 2010. 
$\S 1^{\circ}$ Para atendimento ao disposto no caput deste artigo, o Produtor de Biodiesel deverá encaminhar à ANP, solicitação assinada pelo representante legal da empresa, contemplando justificativas técnicas e informações relacionadas ao volume de produto, destino e prazo de fornecimento ${ }^{49}$.

Forte regulação, prévia autorização para realizar procedimentos produtivos e comerciais, bem como, pouca flexibilização das normas e procedimentos são marcas das resoluções da ANP neste setor (vide Regulamento Técnico $n^{\circ}$ 02/2013, da Resolução ANP $N^{\circ}$ 30/2013 e Certificação do Biodiesel da Resolução ANP $n^{\circ}$ 14/ 2012). Tais ações são extremamente burocratizadas e inúmeras são as exigências que somente grandes agroindústrias conseguem cumprir os requisitos estabelecidos. Há claramente contradição entre as normas, sobretudo na política nacional de produção de biodiesel e incentivo à agricultura familiar:

Art. 3o 0 biodiesel necessário à adição obrigatória ao óleo diesel deverá ser fabricado preferencialmente a partir de matérias-primas produzidas pela agricultura familiar, e caberá ao Poder Executivo Federal estabelecer mecanismos para assegurar sua participação prioritária na comercialização no mercado interno ${ }^{50}$.

Além disso, há lacunas (que podem ser voluntárias ou involuntárias) nessas resoluções, no sentido dado por Bobbio para a norma jurídica ${ }^{51}$, que vêm impossibilitando sua efetividade. Souza e Paulillo demonstraram que as regras de leilões de compra de biodiesel, constantes em resoluções da ANP, vêm contribuindo para o favorecimento da produção de soja proveniente do setor de agroindústrias do centro-oeste brasileiro. Essa estratégia foi criada para garantir a compra da safra do grão em grandes lotes, facilitar o escoamento e diminuir custos de frente para exportação.

Nesta seara concentra-se uma das grandes contradições da situação atual do sistema agroindustrial do biodiesel com os objetivos sociais desta política agrícola. Os produtores da

\footnotetext{
${ }^{49}$ ANP - ANP - AGÊNCIA NACIONAL DO PETRÓLEO, GÁS NATURAL E BIOCOMBUSTÍVEIS. Resolução ANP n $^{\circ} 30$ de 06 de agosto de 2013. Disciplina a atividade de produção de Biodiesel, que abrange construção, ampliação de capacidade, Modificação, operação de planta produtora e comercialização de Biodiesel, condicionada à prévia e expressa autorização da ANP. Disponível em: <https: / /www.legisweb.com.br/legislacao/?id=257409>. Acesso em: 14 jul. 2016.

${ }^{50}$ BRASIL. Lei $n^{\circ} 13.033$, de 24 de setembro de 2014. Dispõe sobre a adição obrigatória de biodiesel ao óleo diesel comercializado com o consumidor final; altera as Leis nos 9.478, de 6 de agosto de 1997, e 8.723, de 28 de outubro de 1993; revoga dispositivos da Lei no 11.097, de 13 de janeiro de 2005; e dá outras providências. Diário Oficial da República Federativa do Brasil, Brasília, DF, 25 set. 2014. Disponível em: <http://www.planalto.gov.br/ccivil_03/_Ato2011-2014/2014/Lei/L13033.htm\#art6>. Acesso em: 09 jun. 2015.

${ }^{51}$ BOBBIO, N. Teoria do Ordenamento Jurídico. 10 ed. Brasília: Edunb, 1999.
} 
agricultura familiar pouco estão inseridos no sistema de produção de biodiesel. Os leilões de compra de biodiesel realizados pela ANP têm sido divididos em dois lotes onde, no primeiro há a exigência de que as agroindústrias de biodiesel possuam o Selo Combustível Social e, no segundo lote a exigência do selo é flexibilizada. Isto abre espaço para que agroindústrias que não tenham realizado os contratos de suprimentos de matéria-prima como agricultores familiares tenham acesso ao mercado ${ }^{52}$.

Essas são apenas algumas das contradições normativas que ocasionam disparidades no sistema de produção do biodiesel no Brasil, as quais geram dificuldades para o sucesso do PNPB. Os desdobramentos políticos, econômicos e sociais nas dinâmicas da produção de biodiesel, sobretudo para a agricultura familiar brasileira, permeiam setores indiretos, que por vezes detém o monopólio dos interesses, estabelecendo normas que muitas vezes passam despercebidas, mas que acabam por distorcer políticas nacionais voltadas para minorias.

Isto reforça a compreensão de que a norma jurídica não pode ser tomada como um fim em si mesma, muitas vezes há embates teleológicos de normas diversas ou interesses políticos conflitantes que extrapolam o campo jurídico. É preciso entender que na complexidade socioambiental do mundo contemporâneo ocorrem fatos que extrapolam o campo jurídico, que somente podem ser compreendidos com o auxílio de outros campos de conhecimento como o econômico, político tecnológico ou social. Por esta razão, o campo jurídico precisa, cada vez mais, valer-se dos outros campos para subsidiar de forma legítima o seu instrumento - a norma.

\section{CONCLUSÃO}

Ao estudar a influência da norma jurídica como instrumento de concretização dos objetivos institucionais do biodiesel no Brasil, foi possível verificar, dentre outras conclusões, que há aspectos que extrapolam o campo jurídico os quais influenciam diretamente na teleologia normativa.

A ideia de transversalidade da norma jurídica tem como propósito inserir nos outros campos de conhecimento a finalidade de determinado conjunto normativo, no caso a produção brasileira de biodiesel, de modo que esses outros campos possam suprir deficiências normativas para que os objetivos finais se concretizem em prol não de grupos particulares (agronegócio),

\footnotetext{
${ }^{52}$ SOUZA, J. D. F.; PAULILLO, L. F. O biodiesel brasileiro: matérias-primas, agroindústrias e a agricultura familiar. $48^{\circ}$ Congresso da Sociedade Brasileira de Economia, Administração e Sociologia Rural. Campo Grande, 2010, p. 12.
} 
mas da sociedade, setores frágeis (agricultura familiar) e do ambiente biofísico. Somente com esse diálogo interdisciplinar a norma pode servir como a principal forma de estabelecer limites e possibilidades para a vontade humana em relação à sociedade e ao ambiente biofísico.

A norma jurídica sobre o biodiesel no Brasil apresenta antinomias e lacunas, as quais são a causa do insucesso do Programa Nacional de Produção e Uso de Biodiesel, voltado a fomentar a melhoria social da agricultura familiar brasileira. Por isso, a transversalidade da norma, proveniente principalmente da Política Energética Nacional, não surtiu o efeito esperado nas normas instrumentais das políticas públicas propostas para o setor de biodiesel.

Nesta linha de raciocínio, os dados apresentados e analisados tornam visível a necessidade do campo jurídico dialogar com outros campos de conhecimento, com vistas a incorporar fatos alheios ao Direito em suas aplicações da norma no mundo concreto. A questão ambiental exige este tipo de abertura do campo jurídico para que a norma cumpra seus objetivos emancipatórios em relação à sociedade. Esse fenômeno conhecido como transversalidade da norma deve permear não só a questão do biodiesel, mas quaisquer temas socioambientais que exijam a norma como instrumento de mudanças.

\section{REFERÊNCIAS}

ABIOVE - ASSOCIAÇÃO BRASILEIRA INDÚSTRIAS ÓLEOS VEGETAIS. Biodiesel: matérias-primas para produção. 2015. Disponível em:

<http://www.abiove.org.br/site/index.php?page=estatistica\&area=NCOyLTE=> Acesso em 05 dez. 2015.

ABREU, Y. V. Biodiesel no Brasil em três hiatos: selo combustível social, empresas e leilões, 2005 a 2012. Málaga: Universidade de Málaga, 2012.

ALVES, A. C. Fundamentos do Direito e meio ambiente. In: PHILIPPHI JR., A.; ALVES, A. C. (Editores). Curso interdisciplinar de direito ambiental. São Paulo: Manole, 2005.

ANP - AGÊNCIA NACIONAL DO PETRÓLEO, GÁS NATURAL E BIOCOMBUSTÍVEIS. Boletim mensal do biodiesel. Novembro, 2015a. Disponível em:

<http: / /www.anp.gov.br/?pg=78672\&m=\&t1=\&t2=\&t3=\&t4=\&ar=\&ps=\&1449790252217>. Acesso em: 05 dez. 2015.

. Resolução ANP $n^{\circ} 30$ de 06 de agosto de 2013. Disciplina a atividade de produção de Biodiesel, que abrange construção, ampliação de capacidade, Modificação, operação de planta produtora e comercialização de Biodiesel, condicionada à prévia e expressa autorização da ANP. Disponível em: <https://www.legisweb.com.br/legislacao/?id=257409>. Acesso em: 14 jul. 2016. 
. Produção de biodiesel. 2016. Disponível em: <http://dados.gov.br/dataset/biodieselproducao>. Acesso em: 11 jul. 2016.

ANTUNES, P. B. Direito ambiental. 1. ed. São Paulo: Atlas, 2013. 1433 p.

BOBBIO, N. Teoria do Ordenamento Jurídico. 10 ed. Brasília: Edunb, 1999.

BRASIL. Estatuto da Frente Parlamentar da Agropecuária. Brasília, 2014. Disponível em: <http://www.fpagropecuaria.org.br/estatuto>. Acesso em: 12 jul. 2016.

. Frentes Parlamentares da Câmara dos Deputados. 2016a. Disponível em:

<http://www.camara.leg.br/internet/deputado/Frente_Parlamentar.asp>. Acesso em: 12 jul. 2016.

. Lei $n^{\circ} 9.478$, de 6 de agosto de 1997. Dispõe sobre a política energética nacional, as atividades relativas ao monopólio do petróleo, institui o Conselho Nacional de Política Energética e a Agência Nacional do Petróleo e dá outras providências. Diário Oficial da República Federativa do Brasil. Brasília, DF, 7 ago. 1997. Disponível em: <http://www.planalto.gov.br/ccivil_03/LEIS/L9478.htm>. Acesso em: 09 jun. 2015.

. Lei $\mathrm{n}^{\circ} 11.097$, de 13 de janeiro de 2005. Dispõe sobre a introdução do biodiesel na matriz energética brasileira; altera as Leis nos 9.478, de 6 de agosto de 1997, 9.847, de 26 de outubro de 1999 e 10.636, de 30 de dezembro de 2002; e dá outras providências. Diário Oficial da República Federativa do Brasil. Brasília, DF, 14 jan. 2005. Disponível em: <http://www.planalto.gov.br/ccivil_03/_ato2004-2006/2005/Lei/L11097.htm>. Acesso em 09 jun. 2015.

. Lei $\mathrm{n}^{\circ} 12.490$, de 16 de setembro de 2011. Altera as Leis nos 9.478 , de 6 de agosto de 1997, e 9.847, de 26 de outubro de 1999, que dispõem sobre a política e a fiscalização das atividades relativas ao abastecimento nacional de combustíveis e dá outras providências. Diário Oficial da República Federativa do Brasil. Brasília, DF, 19 set. 2011. Disponível em: <http://www.planalto.gov.br/CCIVIL_03/_Ato2011-2014/2011/Lei/L12490.htm> Acesso em: 9 jun. 2015.

. Lei $n^{\circ} 9.847$, de 26 de outubro de 1999. Dispõe sobre a fiscalização das atividades relativas ao abastecimento nacional de combustíveis, de que trata a Lei $\mathrm{n}^{\circ} 9.478$, de 6 de agosto de 1997, estabelece sanções administrativas e dá outras providências. Diário Oficial da República Federativa do Brasil. Brasília, DF, 27 out. 1999. Disponível em: <http://www.planalto.gov.br/CCivil_03/LEIS/L9847.htm>. Acesso em: 09 jun. 2015.

. Lei $n^{\circ} 13.033$, de 24 de setembro de 2014. Dispõe sobre a adição obrigatória de biodiesel ao óleo diesel comercializado com o consumidor final; altera as Leis nos 9.478, de 6 de agosto de 1997, e 8.723, de 28 de outubro de 1993; revoga dispositivos da Lei no 11.097, de 13 de janeiro de 2005; e dá outras providências. Diário Oficial da República Federativa do Brasil. Brasília, DF, 25 out. 2014. Disponível em: <http://www.planalto.gov.br/ccivil_03/_Ato20112014/2014/Lei/L13033.htm\#art6>. Acesso em: 09 jun. 2015.

. Lei $\mathrm{n}^{\circ} 13.263$, de 23 de março de 2016. Altera a Lei $\mathrm{n}^{\circ}$ 13.033, de 24 de setembro de 2014, para dispor sobre os percentuais de adição de biodiesel ao óleo diesel comercializado no 
território nacional. Diário Oficial da República Federativa do Brasil. Brasília, DF, 24 mar. 2016. Disponível em: <http://www.planalto.gov.br/ccivil_03/_Ato2015-2018/2016/Lei/L13263.htm>. Acesso em: 12 jul. 2016.

. Medida provisória $\mathrm{n}^{\circ} 688$, de 18 de agosto de 2015. Dispõe sobre a Lei no 9.478 , de 6 de agosto de 1997, que institui o Conselho Nacional de Política Energética Executivo dá outras providências. Diário Oficial da República Federativa do Brasil. Brasília, DF, 18 ago. 2015. Disponível em: <http://www.planalto.gov.br/ccivil_03/_Ato2015-

2018/2015/Mpv/mpv688.htm\#art4>. Acesso em: 10 out. 2015.

CÉSAR, A.D.S.; BATALHA, M.O. Biodiesel production from castor oil in Brazil: a difficult reality. Energy Policy, 38: 4031-4039, 2010.

CONAB - COMPANHIA NACIONAL DE ABASTECIMENTO. Séries históricas de área plantada, produtividade e produção, relativas às safras 1976/77 a 2014/15. Brasília: CONAB, 2015. Disponível em:

<http://www.conab.gov.br/conteudos.php?a=1252\&\&Pagina_objcmsconteudos=2\#A_objcmscont eudos>. Acesso em 05 dez. 2015.

DANTAS, M. R.; PINHEIRO, R. J. Marco jurídico do biodiesel e o modelo regulatório brasileiro. Direito E-nergia. Ano 5, v. 8, 2013.

EPE - EMPRESA DE PESQUISA ENERGÉTICA BRASILEIRA. Balanço energético nacional 2015: ano base 2014. Rio de Janeiro : EPE, 2015.

FLORIANI, D. Crítica da razão ambiental: pensamento e ação para a sustentabilidade. São Paulo: Annablume, 2013.

HALL, J.; MATOS, S.; SEVERINO, L. Brazilian biofuels and social exclusion: established and concentrated ethanol. Journal of Cleaner Production, 17:577-585, 2009.

LEIS, H. R. A Modernidade (In)sustentável. Petrópolis: Vozes, 1999.

LEITE, A. D. A energia no Brasil. 2 ed. Rio de Janeiro: Elsevier, 2007.

LEITE, J. R. M. Sociedade de risco e estado. In: CANOTILHO, J. J. G.; MORATO, J. R.

(organizadores). Direito constitucional ambiental brasileiro. 4 ed. ver. São Paulo: Saraiva, 2011.

LEITE, J. R. M. \& AYALA, P. A. Direito ambiental na sociedade de risco. Rio de Janeiro: Forense Universitária, 2002.

MDA - MINISTÉRIO DO DESENVOLVIMENTO AGRÁRIO. Programa Nacional de Produção e Uso de Biodiesel: inclusão social e desenvolvimento territorial. Brasília: MDA, 2010.

MDA - MINISTÉRIO DO DESENVOLVIMENTO AGRÁRIO. Informações do MDA e do INCRA. Brasília: MDA, 2015. 
MEADOWS, D.; MEADOWS, D.; RANDERS, J; BEHRENS, W. W. Limites do crescimento. 2.ed. São Paulo: Editora Perspectiva, 1978.

MILARÉ, É. Direito do ambiente. 8. ed. São Paulo: Revista dos Tribunais, 2013.

OBERMAIER, M.; ROVERE, E. L. Vulnerabilidade e resiliência socioambiental no contexto da mudança climática: o caso do Programa Nacional de Produção e Uso de Biodiesel (PNPB).

Parcerias Estratégicas, v.16, n.33, p. 109-134, 2011.

PEREIRA, A. C. A.; PEREIRA, J. E. A. O direito à energia no contexto dos humanos. Sequência, n. 53, p. 29-42, dez., 2006.

PETROBRAS. Relatório de administração e balanço contábil de 2014. Rio de Janeiro: Petrobras Biocombustível S.A. 2015.

ROMEIRO, A. R. Desenvolvimento sustentável: uma perspectiva econômico-ecológica. Estudos Avançados, v. 26, n. 74, 2012.

SANCHES, L. A. U. Curso de direito da energia: da história, tomo I. São Paulo: Instituto Geodireito, 2011.

SASSINI, V. Pauta sob pressão da bancada ruralista. Correio Braziliense, Caderno de Política. Edição 07 fev. 2011, p. 4. Disponível em:

<http://www2.senado.leg.br/bdsf/bitstream/handle/id/48454/noticia.htm?sequence=1 >. Acesso em: 11 jul. 2016.

SILVA, J. A. Avaliação do Programa Nacional de Produção e Uso do Biodiesel no Brasil - PNPB. Política Agrícola, v. 22, n. 3, 2013.

SILVA, J. A. Princípios do processo de formação das leis no direito constitucional. São Paulo: Editora Revista dos Tribunais, 1964.

SOUZA, J. D. F.; PAULILLO, L. F. O biodiesel brasileiro: matérias-primas, agroindústrias e a agricultura familiar. $48^{\circ}$ Congresso da Sociedade Brasileira de Economia, Administração e Sociologia Rural. Campo Grande, 2010.

ZAPATA, C.; VASQUEZ-BRUST, D.; PLAZA-ÚBEDA, J. Productive inclusion of smallholder farmers in Brazil's biodiesel value chain: programme design, institutional incentives and stakeholder constraints. Working Paper, 73, Brasília: International Policy Centre for Inclusive Growth (IPC), UNDP, 2010. 